\title{
LA MÁQUINA LITERARIA DE MAURICE BLANCHOT
}

\author{
Constantino Villegas Burgos \\ doi: 10.11144/Javeriana.uph37-74.mlmb
}

\section{RESUMEN}

A diferencia de muchas imágenes del pensamiento dominantes en la filosofía y centradas en la búsqueda de fundamentos cuya coherencia se encuentra en lógicas binarias o relaciones biunívocas, la filosofía de Gilles Deleuze y Félix Guattari es un pensamiento por máquinas que producen multiplicidades puras en virtud de diferencias intensivas. Lo importante con las máquinas no es definirlas -no son delimitables- ni comprenderlas -son asignificantes-, sino que funcionen en la medida en que varios flujos circulan en ellas, entremezclándose o cortándose. Aun cuando toda máquina reúne elementos heterogéneos, las máquinas literarias son interesantes en cuanto pueden alcanzar un nivel de lo fragmentario tal que se exprese la potencia determinante de las diferencias intensivas. El artículo experimenta con la máquina literaria de Maurice Blanchot -en especial con su idea de lo neutro- en busca de operaciones que permitan desarticular los fundamentos (paradigmas, bivalencias, binarismos) de las imágenes del pensamiento dominantes.

Palabras clave: máquina; diferencia; fragmentario; binarismo; neutro

Universidad del Rosario, Bogotá, Colombia.

Correo electrónico: constantino.villegas@urosario.edu.co

Para citar este artículo: Villegas Burgos, C. (2020). La máquina literaria de Maurice Blanchot. Universitas Philosophica, 37(74), 197-230. ISSN 0120-5323, ISSN en línea 2346-2426. doi: 10.11144/Javeriana.uph37-74.mlmb 


\title{
MAURICE BLANCHOT'S LITERARY MACHINE
}

\begin{abstract}
Unlike many dominant images of thought that are centered on searching for foundations whose coherence is found in binary logics or biunivocal relations, Gilles Deleuze and Félix Guattari's philosophy constitutes a way of thinking through machines that produce pure multiplicities by virtue of intensive differences. What is important with regards to machines is to refrain from any attempt at defining or understanding them-they cannot be delimited and are a-signifying-and to try to make them work, such that various flows of thought may circulate through them, intermingling with and interrupting each other. Even though any machine groups together many heterogeneous elements, literary machines are interesting insofar as they can reach a level of the fragmentary whereby the determinant potency of intensive differences can be expressed. This article experiments with Maurice Blanchot's literary machine-especially with his idea of the neuter-to discover operations that could help to dismantle the foundations (paradigms, bivalences, binarisms) of dominant images of thought.
\end{abstract}

Keywords: machine; difference; fragmentary; binarism; neuter 
Allende las ideas del bien y el mal se extiende un campo. Nos encontraremos allá.

(Rumi, 2005, p. 123) ${ }^{1}$

\section{Introducción}

Un SOBREVUELO por la historia de la filosofía postsocrática podría llevarnos a reconocer un tema común más allá de algunas variaciones: el deseo de encontrar o construir los fundamentos de lo que hace pensar, de lo que fuerza al pensamiento, ya sea Dios, el mundo o lo humano, además de los asuntos habitualmente urgentes en la vida política, moral y artística de las sociedades. Las empresas filosóficas se han instalado en la indagación por formas eternas, causas primeras, principios de la razón y otros tantos centros conceptuales capaces de dar confort intelectual al individuo presa del asombro. Podríamos decir, con Sloterdijk (2006), que la historia de las ideas filosóficas es la historia de la construcción de esferas cuyos espacios interiores acogen lo amigable y mantienen a raya lo desagradable. La interioridad filosófica ha favorecido al buen sentido, la sobriedad del juicio y la concordia de las facultades, mientras que el sinsentido, la locura y la discordia de las facultades se han visto como parte de un afuera indigno o indeseable. De ahí que, en las imágenes del pensamiento dominantes, la filosofía opere como especie de farmacopea o terapéutica habilitada para afrontar situaciones extremas que adquieren con ella un carácter moderado. Sin embargo, no es posible aplacar definitivamente la tensión que produce el afuera que está ahí, como un espectro que impide el cierre, la totalización o la sistematización anhelada del pensamiento. Pues no hay pensamiento que no implique siempre ya el retorno de su otro, de su doble, del enemigo oculto bajo el amigo, de la locura como hermana de la razón, del sentido como donación del sinsentido. Es justo lo impensable aquello que, al desquiciar o sacar de sus goznes a las facultades pensantes, fuerza al pensamiento hacia un movimiento productivo, extático, más allá del buen sentido, en un espacio que la filosofía se ha empeñado en denegar. Pensar lo impensable es quizá la preocupación de una filosofía por venir. Para eso

1 Todas las traducciones de citas de textos no disponibles o de difícil acceso en español son propias. 
es necesario dar el paso/no más allá (le pas au-delà $)^{2}$, rumbo a un sin-fondo que se reconquista, según dice Deleuze (2005) que hizo Nietzsche, cuando se llega a "discernir mil voces en sí mismo" (p. 82), haciéndolas hablar a todas.

Pensar lo impensable: he ahí una aporía filosóficamente conductora, además de una exigencia que problematiza la condición limítrofe del pensamiento como creación, en una cercanía radical con la experiencia mística que abandona el acto de pensar en virtud de una iluminación. Movidos por el deseo de liberar en la filosofía fuerzas que deshagan los viejos fundamentos formadores de interioridad apaciguada, pero también por la pasión de la diferencia que acepta la inoculación de lo extraño, del afuera, encontramos que los binarismos o bivalencias condicionan, definen y trazan límites para lo pensable, imponiendo jerarquías inscritas en las imágenes del pensamiento dominantes. Enfocándose en el discurso, Barthes (2004) se ha referido a dichos binarismos como paradigmas, cuyo núcleo es "la oposición de dos términos virtuales de los cuales actualizo uno al hablar" (p. 51). Por supuesto, las parejas aludidas hasta ahora (adentro/afuera, pensable/ impensable) participan del esquema binario. De ahí que su uso implique una lectura parentética, irónica, una distancia íntima atenta a la carga jerárquica del lenguaje y, con todo, consciente de la posibilidad de movilizar una potencia de dislocación, deriva o deslizamiento del sentido en el entre que separa los términos de cada pareja. Podemos aceptar - con Barthes (2004) - que la escritura es "fundamentalmente asertiva" (p. 96) y no cesa de plantear bivalencias; pero no por eso debemos comprometernos con las estructuras bivalentes, pues quizá la

2 En la introducción de la traducción al inglés, Lycette Nelson explica que el sentido de la expresión le pas au-delà es cuádruple: "Como señala Derrida, el juego no es solo un juego de palabras, sino de palabras y cosas. Las posibilidades de traducción del título completo son en realidad cuádruples, pues tanto pas como au-delà pueden tomarse como sustantivos o adverbios (pas es tanto un paso como parte del adverbio negativo ne-pas; au-delà significa "más allá, pero también se da como "l'audelà", lo más allá); el significado de la frase completa cambia dependiendo de la función semántica de cada una de sus partes". ["As Derrida points out, the play is not just a play of words, but of words and things. The possibilities for translating the whole title are actually quadruple, since both pas and au-dela can be taken either as nouns or adverbs (pas is both a step and part of the negative adverb ne-pas; au-delà means "beyond", but also occurs as "l'au-delà", the beyond); the meaning of the entire phrase changes depending on the semantic function of each of its parts" (1992, p. xvi)]. El paréntesis que ha usado De Peretti, en su traducción al castellano de Le pas au-delà (Paidós, 1994), como "paso (no) más allá" no mantiene ese deslizamiento del sentido en cuatro direcciones. Me parece que la barra sí, y por eso creo que es preferible ceñirse, al menos en eso, a la traducción al inglés. 
escritura pueda "atraer al lenguaje a una posibilidad de decir que diría sin decir el ser y sin tampoco negarlo" (Blanchot, 2008, 496).

Preliminarmente, necesitamos una filosofía que no deseche lo aporético como un escándalo de la razón, que no pretenda resolver las tensiones por la vía dialéctica ni tampoco asuma una distancia dogmática o nihilista. Necesitamos una filosofía capaz de retener la fuerza de la diferencia en sí misma, insubordinada a la identidad, prolífica en la multiplicidad. La filosofía de Gilles Deleuze (y Félix Guattari) sirve como modelo para romper con las jerarquías y binarismos que aprisionan las intensidades del pensamiento. Ante todo, de ella nos interesa el concepto de máquina -en general- porque permite experimentar con multiplicidades, pensar por fragmentos fuera del orden totalizante de la razón convencional. Y en particular, el concepto de máquina literaria es atractivo en la medida en que introduce un plano cuya relación con la filosofía es problemática (es decir, creativa, potente): la literatura, ese afuera que crece en el límite indecidible de la cuestión misma de su esencia. La literatura, dice Derrida (1998a), "no existe", y "no permanece en casa, permanentemente [à demeure] en la identidad de una naturaleza ni aun en un ser histórico idéntico a sí mismo" (p. 29) ${ }^{3}$. Y quizás se debe a su esencia inesencializable el poder que tiene para desarmar los paradigmas incrustados en las imágenes del pensamiento dominantes. Deleuze desplegó el concepto de máquina literaria en su obra sobre Proust (Deleuze, 1972) y lo repitió después, con Guattari, en su libro sobre Kafka y la "literatura menor" (Deleuze \& Guattari, 1990). También, de paso, ambos lo aplicaron a Blanchot en El Anti Edipo (Deleuze \& Guattari, 2016), a propósito de lo fragmentario que produce multiplicidades cuya relación se da por su propia diferencia. En ese pliegue no desarrollado de referencias a Blanchot se incuba nuestro trabajo.

El artículo propone una explicación de la máquina literaria de Blanchot bordeando la obra de autores en que lo maquínico se repite, diferenciándose, en busca de una serie que permita expresar la potencia contra los binarismos y jerarquías del pensamiento. Aunque la relación entre pensamiento y escritura nunca puede tematizarse definitivamente, intentaremos mostrar que lo que pasa por una obra literaria tiene efectos filosóficos. Pequeñas excursiones por la obra

3 «(...) elle n'existe pas, elle ne se maintient pas à demeure dans l'identité d'une nature ou même d'un être historique identique à lui-même ». 
de Valéry, Kafka, Proust y Musil servirán para problematizar el peso atributivo del lenguaje en relación con la personología de la gramática literaria, esto es, la estructura jerarquizante por excelencia en la escritura. El criterio de selección que reúne a esos autores es a duras penas pertinente según las exigencias de un método filosófico o de teoría literaria, pero puede justificarse desde una filosofía, como la de Deleuze y Guattari, que encuentra fértil una serie de diferencias que (se) repiten. Lo que nos ha llamado la atención en ellos es la ausencia de centro narrativo, el descentramiento como operación que hace de pronombres, personajes y voces singularidades nómadas. En cada uno aparece, a su manera, un gesto maquínico que reúne lo incongruente, abre límites y deshace paradigmas. Ese gesto tiene en Blanchot una potencia inusitadamente rica, tal vez porque su obra es filosófica hasta la erudición y literaria con plena libertad artística, una rareza tanto en la filosofía como en la literatura (sobre todo en la primera). Mas no se trata, en todo caso, de que Blanchot escribiera ensayos "filosóficos" $y$ novelas o récits. La fuerza de la obra blanchotiana está en la desenvoltura con que imbrica una multitud de estilos, tonos y tesituras, manteniendo su diferencia en una escritura fragmentaria. Por lo general, cuando se intenta derivar de la literatura un pensamiento en términos filosóficos, se corre el riesgo de dar lo que parece una metábasis, que en Aristóteles sería un "paso [ilegítimo] a otro género [ $\mu \varepsilon \tau \dot{\alpha} \beta \alpha \sigma i s$

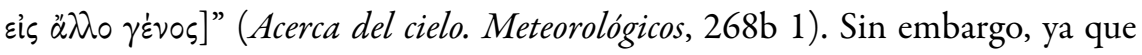
en Blanchot ningún género está en una posición de soberanía, el paso de lo literario a lo filosófico (y viceversa) no se detiene por el temor de una transgresión -afirmada, negada en la inminencia de su prohibición-, pues ella misma crea el umbral que se vacía dejando proliferar las diferencias ${ }^{4}$.

Dicho de otra manera, Blanchot no produce un agregado de conceptos y figuras, no procede por combinaciones ni por síntesis dialécticas, sino que hace eclosionar diferencias que no tiene mucho sentido llamar filosóficas o literarias. La fuerza de su escritura está en el entre que, como observa Derrida (1998a), está

4 La transgresión es la prohibición misma, el paso/no más allá (le pas au-delà) que nunca puede afirmarse sin negarse: "el círculo de la ley es el siguiente: es preciso que haya franqueamiento para que haya límite, pero solo el límite, en la medida en que es infranqueable, requiere ser franqueado, afirma el deseo (el paso en falso) que ya siempre ha franqueado la línea con un movimiento imprevisible" (Blanchot, 1994, p. 54). 
marcado por una "doble imposibilidad" (p. 10)5 : no puede decidirse por un género, pero tampoco puede permanecer (demeurer) en lo indecidible. Esa aporía nos acercará a la idea, recurrente en Blanchot, de que no es un autor quien escribe, sino la diferencia en sí misma. En ese sentido, la noción de máquina literaria servirá para mostrar cómo los cortes y rupturas de una escritura fragmentaria producen síntesis disyuntivas inconcluyentes, repeticiones sin origen, diferencias puras. En el límite que, más que separar lo diferente, es él mismo la diferencia, aparece lo que Blanchot (1994) ha llamado "lo neutro", relación siempre desplazada pero también "en desplazamiento con relación a sí misma" (p. 34). No podemos tematizar lo neutro ni definirlo sino, por mucho, mostrar sus efectos sobre el pensamiento bivalente y sus salidas convencionales, como la vía de un tercero que no desarma las estructuras relacionales biunívocas. A medida que lo neutro emerge de la máquina literaria de Blanchot, trataremos con su repetición en la obra de Barthes, que, consciente del peso asertivo de las sistematizaciones, de lo tético, ha preferido mostrar figuras de lo sutil y lo delicado sin renunciar a la expresión de un activo de lo Neutro ${ }^{6}$ que deshace paradigmas.

Finalmente, aclaremos algo implícito: no hay aquí una "lectura" de Blanchot a partir de Deleuze, por mucho que Blanchot vea en lo neutro la fuerza de la pasión, la pasividad o el paso/no más allá. Así como la idea de máquina literaria habilita una expresión de la potencia desatada por la escritura fragmentaria en Blanchot, la idea misma queda afectada por su aplicación (como intentaré mostrar) en el sentido de poder decir, después de Blanchot, que toda máquina (literaria o no) funciona por operaciones de lo neutro contra la conminación a elegir entre los términos formadores de jerarquías. O lo que es lo mismo: en una multiplicidad hay siempre una potencia de lo neutro. Con esa conjetura podría releerse en Deleuze y Guattari todo lo relativo a las máquinas, pero ese no es el propósito que nos convoca. Pues debemos insistir en la máquina literaria de Blanchot para mostrar en qué sentido lo maquínico se encuentra en la manera en que la diferencia escribe por repeticiones que, escindiendo al escritor y sus

$5 \ll$ double impossibilité ».

6 Lo Neutro con mayúscula inicial se refiere al término de Barthes (tal como él mismo lo escribía); en cambio, lo neutro con minúscula inicial hace alusión al uso de Blanchot. 
singularidades, abren lo fragmentario como el entre indecidible que distancia y aproxima las instancias de la literatura. Previsiblemente, la tematización del límite y sus transgresiones y prohibiciones nos forzará a hablar de la muerte, no en virtud de su ubicuidad como tema literario o de su gravedad filosófica, sino, en cambio, por su fuerza móvil -en el ámbito de lo problemático-, que determina toda escritura.

\section{2. ¿Qué puede una máquina?}

EMPECEMOS POR NOTAR un efecto de la máquina literaria: la ausencia de centro que produce una escritura fragmentaria. El narrador de A la busca del tiempo perdido (Proust, 2015) nos da un modelo de la superficie que recibe (y produce) series de los signos más variados, que no siente ni percibe nada, sino que responde a señales como una araña que se mueve según los temblores de su tela. Para el narrador de Proust, "un punto es el todo [...], también él teje una tela, que es su obra, a cuyas vibraciones responde al tiempo que la teje" (Deleuze, 2008, p. 52). Los puntos que aparecen en la visión del narrador son como destellos - una voz, unos ojos, un olor- en una nebulosa (un rostro) de contornos difusos, "formaciones molares o colectivas que implican singularidades repartidas al azar" (Deleuze \& Guattari, 2016, p. 74). En la experimentación proustiana, las singularidades forman series de signos que proliferan en todas las direcciones, con lo que no hay un centro unificador, ni desde el ámbito interpretativo, ni mucho menos en una pretendida intención artística del autor. La ausencia de centro -el descentramiento como procedimiento- es concomitante con un funcionamiento por fallos e intermitencias, cortes y rupturas, que impiden la remisión a un todo como garantía de la vuelta a una unidad originaria o la promesa de una unidad por venir (Deleuze \& Guattari, 2016). Allí donde, como en $A$ la busca del tiempo perdido (Proust, 2015), los hiatos son productivos y las disyunciones inclusivas, no podemos seguir hablando de un autor ni de una obra cerrados, contenidos, sino de máquinas en un sentido que no es de ningún modo metafórico. Hablamos de máquinas en el sentido más concreto, qua sistemas de cortes que efectúan extracciones en un flujo continuo:

En la máquina literaria de la Recherche du temps perdu, es sorprendente hasta qué punto todas las partes son producidas como lados disimétricos, 
direcciones rotas, cajas cerradas, vasos no comunicantes, compartimentos, en los que incluso las contigüidades son distancias, y las distancias afirmaciones, pedazos de puzle que no pertenecen a uno solo, sino a puzles diferentes, violentamente insertados unos en otros, siempre locales y nunca específicos, y sus bordes discordantes siempre forzados, profanados, imbricados unos en otros, siempre con restos. Esta es la obra esquizoide por excelencia (Deleuze \& Guattari, 2016, p. 48).

$\mathrm{Ni}$ organismo que se forma por relaciones articulares, ni mecanismo que opera por conexiones graduales entre términos dependientes: una máquina es una proximidad que reúne términos independientes -allende su distancia o contigüidad- en una vecindad topológica (Deleuze \& Guattari, 1990). Sus agenciamientos comportan el desplazamiento de un centro de gravedad sobre una línea abstracta, sin contorno, no geométrica, "la línea más viva, la más creadora", como las líneas mutantes de la pintura en Pollock (Deleuze, 2008, p. 167). Una máquina es indefinible en el sentido de cualquier filosofía de la representación, primero, porque no es delimitable (definir: trazar límites) y, segundo, porque es asignificante, no hay nada que interpretar ni comprender: sencillamente algo pasa o no pasa por ella, ciertos flujos se entremezclan y se cortan o reconducen. De ahí que cualquier cualificación de una máquina -lingüística, literaria, diabólica- sea siempre un procedimiento provisional que debe tomarse con reservas, pues hay elementos de todo tipo conviviendo en ella, fluyendo en ella. Toda máquina es máquina de máquinas. Una máquina energía puede conectar con una máquina órgano, como en la máquina heliorrectal del presidente Schreber (Deleuze \& Guattari, 2016). La máquina diabólica del matrimonio se reúne con la máquina epistolar y la máquina burocrática en Kafka (Deleuze \& Guattari, 1990). No hay una totalidad llamada literatura -toda totalidad es adyacente, es una parte al lado de las partes- capaz de contener a las máquinas literarias, pues estas funcionan precisamente por la producción de fragmentos que se relacionan entre sí por "su propia diferencia" (Deleuze \& Guattari, 2016, p. 47).

Cuando Deleuze y Guattari piensan en fragmentos que se relacionan entre sí "por su propia diferencia", no están tratando con la diferencia entre algo y algo más, sino con la diferencia que se sustrae a la representación, a la cuádruple raíz de la metafísica tradicional formada por la identidad, la analogía, la oposición y la semejanza (Deleuze, 2002). Al hacerse inaprehensible para la representación, 
la diferencia ya está siempre descentrándose como algo en sí mismo que no comparte la mismidad de la identidad clásica y que debe pensarse, no como aquello entre una cosa y otra - cada una con su identidad asegurada y solo diferentes de-, sino como aquello que produce, que determina a las cosas. Deleuze ha incubado una diferencia intensiva que no es ya la consecuencia de la representación que nos muestra - desde la seguridad de la mismidad- cómo una cosa se distingue de otra. Pues en un pensamiento tal, la diferencia solo puede hallarse en el entre que es, en todo caso, un vacío sin realidad. Si bien la búsqueda de la diferencia intensiva parece afirmarla frente al entre propio de la representación (entendido como el lugar de la diferencia externa), se verá que, una vez inmersos en el pensamiento deleuziano, el entre también se transforma y se convierte en diferencia viva, en distancia afirmada que relaciona los acontecimientos. Es precisamente allí donde las máquinas despliegan su funcionamiento, en las distancias que separan a las partes produciendo multiplicidades puras por síntesis disyuntivas. Deleuze y Guattari (2002) han elogiado en Maurice Blanchot el haber "sabido plantear este problema con todo rigor, al nivel de una máquina literaria” (p. 47), y, aunque nunca llegaron a desplegar la máquina blanchotiana con la concreción con que Deleuze se ocupó de Proust y el tándem se ocupó de Kafka, parece que dejaron la semilla para una línea de fuga o diseminación capaz de tomar como modelo la escritura fragmentaria (o la escritura del desastre) de Blanchot.

Hay un problema cuádruple que se insinúa al hablar de "la máquina literaria de Maurice Blanchot". En primer lugar, el artículo definido "la" determina la cantidad como delimitación extensiva de lo maquínico en una unidad que es precisamente aquello ajeno a un sistema de cortes y extracciones donde cada máquina es máquina de máquinas, y, en relación específica con la obra de Blanchot, el artículo es inadecuado para presentar su devenir siempre fragmentario. En segundo lugar, la cualificación "literaria" es engañosa, no solo -como dijimos antes- porque en una máquina se reúnen elementos heterogéneos (lingüísticos, políticos, eróticos), sino además porque lo "literario" está siempre en riesgo de introducir un espacio sustantivo, la literatura, como dominio distinto, aprehensible, en especial cuando se piensa en relación con la filosofía, cuya insistencia fundamental ha sido -según Derrida- pensar su otro aun para apropiárselo (Derrida, 2006). En tercer lugar, la preposición "de" marca lo genitivo de la relación entre la máquina y Blanchot, aunque una máquina -como se habrá 
descifrado ya- no tiene un origen genético trazable como referencia a un creador, ni siquiera en la autoridad (ni en la autenticidad o verdad) de un auctor que escribe; esto es particularmente problemático en Blanchot, que se enfrenta a la imposibilidad de escribir, a la escritura que borra sus huellas aun antes de escribirlas y que sustrae al escritor en una deriva equipotente a la muerte misma; con lo que llegamos al cuarto punto, a la singularidad que es "Blanchot": ¿quién? ¿Qué puede decir un dato biográfico de ese al que su propio nombre nunca nombra? ¿Qué puede decir un título, sea filósofo o escritor, de aquel que fragmentó la filosofía y la literatura más allá, más acá, de todo límite? ¿Qué hay de las fechas biográficas de nacimiento y muerte que se inscriben en las solapas de sus libros? ¿Qué dicen de uno que narró su propia muerte y, sin embargo, pensó toda una vida en la imposibilidad de morir, en la inautenticidad de toda relación con la muerte?

¿Debe ese problema conducirnos a una o varias soluciones? ¿O podemos mantenerlo en la meseta que siempre desplaza el punto climácico de la solución, que crece por los bordes como un cristal, proliferando sin detenerse, nutriéndose del límite móvil que define su campo? Un problema está determinado por "los puntos singulares que expresan sus condiciones" y, en cuanto tal, no se agota en sus soluciones, sino que subsiste en la idea que organiza "la génesis de las soluciones mismas" (Deleuze, 2005, pp. 83-84). Heidegger expresó un sentir afín cuando dijo que "toda pregunta es una complacencia que nos llena", mientras que "toda respuesta es una pérdida que nos merma" (Heidegger, 2015, p. 36). Pensar lo fragmentario en la escritura de Blanchot, esto es, lo maquínicamente productivo, es un ejercicio de aproximación al umbral crítico en que el problema, en cuanto acontecimiento ideal, despliega singularidades en cuya vecindad se organizan las soluciones. Es decir, lo problemático determina las series de soluciones, y no a la inversa. De ahí que las investigaciones sobre Blanchot predefinidas por el prurito de hallar equivalencias o parecidos de familia ("ies Le dernier homme una novela nietzscheana?”, “¿es lo neutro una noción romántica?”) no lleven a otra cosa que un encierro de lo más rico en su escritura: la producción de multiplicidades que desbordan los límites con que la interpretación crea un espacio estriado de sobrecodificación; esto es especialmente cierto en lo que atañe a la teoría literaria, con su abundancia de métodos, definiciones y categorías. En consecuencia, todo trazo de la máquina será experimental, asistemático; no 
queda más que ubicarse en un estrato y abrir líneas de fuga para ver qué pasa, qué circula, qué posibilidades se ofrecen. Puede ocurrir que aparezcan "puntos paranoicos, puntos de bloqueo o arrebatos delirantes" (Deleuze \& Guattari, 2002, p. 158), pero estaría bien; todo ello haría parte de la composición de una cartografía maquínica, incluso si por eso se gangrenaran ciertas intensidades.

En una obra marcada por la circulación de intensidades, aquello que cotidianamente se llama personaje no puede permanecer mucho tiempo centrado bajo el orden de un nombre, una biografía o la aparente inmediatez de su cuerpo extensivo, sino solo a condición de movilizar un desarreglo que impida cualquier anclaje personológico. Dicha transitoriedad de las partículas personales arrastra también a las personas gramaticales implicadas en toda escritura, empezando por el "yo" que firma un escrito con su narrador hipostasiado. Podría ser de otra manera, pero parece que solo un "yo" en retirada permite que lo múltiple pase por el texto, que el texto sea llevado por la pasión de la diferencia. Sin embargo, dado que una impersonalidad radical sería dogmática, siempre debe haber algunas huellas yoicas en juego. De lo contrario, cualquiera podría advertir que la ausencia del "yo" es apenas una denegación. Cuán difícil es desestratificar la personología de la gramática literaria se ve en que el primer impulso de un escritor descreído del "yo" es proponer una variedad de personajes con sus puntos de vista correspondientes. Pero una multitud de centros no produce un descentramiento, tan solo multiplica los puntos de bloqueo. Por eso, los flujos de intensidades que descentran la personología no circulan por subjetivaciones intermitentes, sino por individuaciones dinámicas, devenires o velocidades que se deslizan en una zona de variación. Otro tanto sucede con los "personajes" de Le dernier homme, obra de Blanchot (1957):

Sin embargo, él era perturbador. Me perturbaba más que los demás. Quizá cambió la condición de todos, quizá solo la mía. Tal vez él era la persona más inútil, más superflua de todas.

¿Y qué si él no me hubiera dicho un día: "no puedo pensar en mí: hay algo terrible allí, una dificultad que se escabulle, un obstáculo que no puede encontrarse"? Y justo después: "él dice que no puede pensar sobre sí mismo: sobre otros, incluso sobre cada uno, pero es como una flecha que viene de muy lejos, que no alcanzará su blanco, y, sin embargo, cuando se detiene y cae, el blanco se sacude en la distancia y viene a su encuentro". En esos momentos, 
él habla muy rápido en una suerte de voz grave: grandes frases que parecen infinitas, que ruedan con el sonido de las olas, un murmullo universal, un canto planetario imperceptible (p. 8). ${ }^{7}$

La apertura de los personajes en Le dernier homme (Blanchot, 1957) es tal que ninguno tiene nombre. No son más que pronombres ("yo", "él", "ella", quizás un "nosotros") diseminados en todos los sentidos. En esa economía gramatical, la escasez de medios es una virtud, ya que cada partícula personal puede extenderse sobre una línea abstracta sin un rumbo predefinido y adquirir cualquier voz. Parafraseando a Musil (2012), se trata de hombres sin atributos que viven en un mundo de atributos sin hombre, de "experiencias sin uno que las viva" (p. 155). Por una resonancia que amplifica las diferencias originales, los personajes permeables hacen que el escritor y sus hipóstasis se diseminen en gradientes, de modo que, entre las singularidades del autor, el narrador y el personaje, proliferan multiplicidades que desarman la carga atributiva del lenguaje sin llegar propiamente a constituir una impersonalidad. En su ensayo a propósito de Musil, Blanchot (2005) reconoce que lo impersonal es tanto el novedoso "poder neutro" de cierta escritura experimental, como también una "amenaza” (p. 180). Pero -a renglón seguido- apunta: "en realidad, Musil se atiene a menudo a un lenguaje intermedio entre la impersonalidad de la verdad objetiva y la subjetividad de su persona" (p. 181). Podría decirse que con el flanear de Ulrich y los vaivenes de la acción paralela se traza un protoplano de inmanencia más allá de cualquier distinción entre sujeto y objeto. Musil (2012) entiende el pensamiento como algo que acontece entre lo personal y lo impersonal, y es ferozmente contracartesiano cuando llama al raciocinio "un estado deplorable, una especie de cólico de todas las circunvoluciones cerebrales” (p. 117) ${ }^{8}$. Estas reflexiones aparecen en

7 «Il gênait, pourtant. Il m’a gêné plus que d'autres. Peut-être a-t-il changé la condition de tous, peutêtre seulement la mienne. Peut-être fut-il le plus inutil, le plus superflu de tous les êtres. / Et s'il mavait dit un jour: "Je ne puis penser à moi : il y a là quelque chose de terrible, une difficulté qui échappe, un obstacle qui ne se rencontre pas. "? Et tout de suite après: "Il dit quil ne peut penser à lui-même : aux autres encore, à tel autre, mais c'est comme une fleche, partie de trop loin, qui n'atteindrait as son but, et pourtant quand elle sarrête et tombe, le but, dans le lointain, frémit, et vient à sa recontre. "A ces instants, il parle très vite et comme à voix basse; de grandes phrases que pairaissent infinies, qui roulent avec un bruit de vagues, un murmure universel, un imperceptible chant planétaire ».

8 Confróntese con la diatriba de Nietzsche (2016b) contra el idealismo alemán: "el espíritu alemán es una indigestión” (p. 797); también contra la profundidad alemana: "[el alemán] digiere mal sus 
un aparte titulado "Un capítulo que se lo puede saltar quien no estime las consideraciones introspectivas", en que las meditaciones de Ulrich sobre un problema matemático aplicado al agua lo arrastran en una deriva hidroterapéutica que remezcla ciertos pensamientos - no atribuibles a Ulrich, al narrador o a Musil- con la síntesis del flujo narrativo-reflexivo de la novela, complicando aún más el problema de la atribución de las palabras.

En El hombre sin atributos se habla con frecuencia de cómo las ideas se relacionan más entre ellas - por solidaridad y afinidad- que con quien parece pensarlas, pero aun así aparecen remitidas a cerebros que las concentran. Blanchot sigue un procedimiento afín, con la enorme salvedad de distribuir las intensidades del pensamiento, no en el espacio extensivo de los cuerpos individuales o colectivos, sino en un spatium inextenso. A diferencia de muchas máquinas literarias que conectan con máquinas sociales, políticas y judiciales distribuidas en el cuerpo de la Tierra, en la extensio de la anima mundi, Blanchot pliega la máquina en la superficie intensiva de la escritura. Kafka, por ejemplo, da impulso a máquinas inescapables que pueden conectar el cuerpo del emperador con un aparato burocrático y una serie de edificios; así, en "La muralla china", un mensajero del emperador lleva un mensaje para ti, pero el palacio imperial es tan vasto, tan lleno, que debe dar brazadas para escurrirse entre la gente, y esfuerzos grandes no le alcanzarían para cruzar siquiera las estancias interiores, e incluso si lo lograra, pasaría milenios atravesando patios y palacetes sin ver nunca la ciudad imperial, el "centro del mundo"' (Kafka, 2012b, p. 151). Incluso, el propio K no es un narrador ni un personaje, sino "un dispositivo tanto más maquínico, un agente tanto más colectivo cuanto que es solo un individuo el que se encuentra conectado a todo eso en su soledad" (Deleuze \& Guattari, 1986, p. 18). En Blanchot (1994), en cambio, hay una llamada de la intimidad que "hace estallar la presencia" o el presente (p. 102), aunque siempre hay algo impenetrable a la espera, como en Thomas l'obscur: Thomas cava su propia tumba, y justo cuando, con una piedra

acontecimientos, nunca 'acaba' con ellos; a menudo, la profundidad alemana no es más que una difícil y reticente 'digestión”' (p. 402).

9 "Es difícil imaginarse semejante ciudad; antes que eso, preferimos creer que Pekín y su emperador son una sola cosa, algo así como una nube que vaga serenamente bajo el sol por los siglos de los siglos", dice el narrador del cuento (Kafka, 2012b, p. 153). 
atada al cuello, se arroja en ella, descubre un cuerpo "mil veces más duro que el suelo", el cuerpo del sepulturero que ya se había instalado allí, que es su propio cuerpo en "el vacío absoluto" (Blanchot, 1950, pp. 38, 39). ${ }^{10}$

Antes del Ulrich sin atributos de Musil y del K de Kafka -sin considerar la fórmula trivial de que Kafka creó a sus precursores-, Valéry propuso como tema general de Monsieur Teste un excurso maquínico: la hiperestesia de la consciencia, lo que Roland Barthes (2004) ha llamado "la consciencia como droga" o "yo hipertrofiado" que produce alucinaciones (p. 149). Teste, cuyo nombre ya convoca un desarreglo múltiple (tête o 'testa', pero también 'testigo,' 'espectador' y 'testículo' [Mathews, 1948, p. xi]), es precisamente un testigo macrocefálico de su propio pensamiento, a la manera de una psicología exponencial que retiene toda afectividad en la cabeza. Teste habla con palabras que "nos hacen creer que el eterno muro entre las mentes se viene abajo" (Valéry, 1960, p. 18) ${ }^{11}$, engendra mezclas monstruosas entre eventos noticiosos, la industria y los gustos de la gente, hace de una retahíla con los nombres de números muy largos una especie de poesía y, también al borde del sueño, tiene accesos de logorrea: "estoy siendo y viéndome a mí mismo, me veo viéndome a mí mismo, y así sucesivamente" (Valéry, 1960, p. 25) ${ }^{12}$; al fin, se duerme, recordando que dormir no le impedirá continuar con cualquier idea. Está claro que un "yo" hipertrofiado exponencialmente conduce a lo que Hegel llamaría "infinitud mala" (schlechte Unendlich$k e i t$ ), una alternación monótona y a escala de lo mismo cual un envolvimiento interminable de muñecas rusas. Lo que frustra el cuerpo sin órganos de Teste es la insistencia de la cabeza en aprisionar las intensidades, conformando un "punto de bloqueo" que resulta en la producción de un cuerpo vacío, como el de ciertos drogadictos, salvo que la droga aquí no es otra cosa que el pensamiento (Deleuze \& Guattari, 2002, p. 158).

Tomemos prestado el alias que G. H. Hartman dio a Derrida para llamar a Blanchot Monsieur Texte. Acaso la distancia que lo separa de Teste y que, en última instancia, hace de su cuerpo sin órganos un lumínico huevo tántrico,

10 «mille fois plus dur que le sol $» ;$ « dans le vide absolu».

11 «ont croire que le mur éternel entre les esprits tombe ».

12 «e suis étant, et me voyant; me voyant me voir, et ainsi de suite ». 
no sea otra cosa que una hiperestesia de los afectos, más allá incluso de lo que Barthes (2004), en su construcción de un "contra-Monsieur Teste", decidió llamar "hiperconsciencia emotiva" (p. 155). Ni consciencia intelectual craneana, ni hipersensibilidad emocional, lo que escribe a Blanchot y se disemina en sus personajes es un despliegue de afectos - de capacidad para afectar y ser afectadopocas veces visto en la literatura y menos aún en la filosofía. Pues no se trata ya de conducir una desestratificación, en todo caso necesaria, de las intensidades aprisionadas en la consciencia para estratificarlas después en el corazón. Tampoco se trata de hacer demasiada violencia al organismo ni a la interpretación, que todo lo atenazan en estratos, al "juicio de Dios" que "construye las reglas mediante las cuales se aprehende el mundo" (Deleuze \& Guattari, 2002, p. 166), pues ese todo puede llevarse consigo la vida y dejarnos con un cuerpo de nada. Blanchot comprendió que la cuestión estriba en prepararse para las micropercepciones, y, en consecuencia, para la conducción de microafectos que pueden -por la fuerza de lo fragmentario- multiplicarse en el otro. Por eso, sus personajes pueden sucumbir por una palabra, y más por su ausencia, ser espantados por un punto, por el silencio de quien no duerme en la habitación contigua o, peor aún, duerme sin soñar (Blanchot, 1957). Para Derrida (1998a), hay en Blanchot una suerte de "necesidad espectral" que rebasa la oposición entre lo actual y lo virtual, donde lo que no sucede llega a pasar con una virtualidad "que no podría ser más opuesta a la efectividad actual” (p. 193) $)^{13}$, como en las muertes de Le dernier homme:

En verdad, él hablaba muy poco, pero su silencio a menudo pasaba desapercibido. Yo creía que él tenía cierta discreción; a veces, que era un poco desdeñoso; a veces, que se retiraba demasiado en sí mismo o fuera de nosotros. Ahora pienso que tal vez él no existió siempre o no existía aún [...] Me convencí de que lo conocí primero cuando estaba muerto, luego cuando estaba muriendo (Blanchot, 1957, pp. 8, 12). ${ }^{14}$

13 «necessité spectrale ; « d’une virtualité qu’on ne saurait plus opposer à l'actuelle effectivité ».

14 «ertainement il parlait peu, mais son silence passait souvent inaperçu. Je croyais à une sorte de discrétion, par fois à un peu de mépris, pas fois à un trop grande recul en lui-même ou hors de nous. Je pense aujourd'hui que peut-être il n'existait pas toujours ou bien qu'il n'existait pas encore. [...] Je me suis persuadé que je l'avais d'abord connu mort, puis mourant ». 
Hay un arte de la sutileza en juego, pero es improbable que se note a primera vista en la máquina. Por muchas precauciones que se tomen para trazar la máquina más allá del mecanismo, lo maquínico no se desprende de su imago técnico-industrial -naturalmente distorsionada- de engranajes y correas, de palancas y cables, un poco, incluso, reminiscente de aquella máquina de la colonia penitenciaria que marca las sentencias en el cuerpo de los condenados (Kafka, 2012a). No viene al caso un reproche a las preferencias léxicas de Deleuze y Guattari, pero es de esperar que lo maquínico evoque un ruido latoso. En una filosofía eo ipso expresiva, ningún término es neutral. Tal vez por eso, en Mil mesetas el rizoma prolifera como figura de lo que en El Anti Edipo ha tomado la forma de la máquina: la conectividad y la heterogeneidad, la multiplicidad, las rupturas asignificantes, las cartografías. No se sigue de ahí que signifiquen lo mismo, pues aparte de no significar nada, cada palabra dice la diferencia en sí misma. Pero es precisamente propio de lo maquínico y de lo rizomático, de lo rizomaquínico, el producir cortes y relevos que hacen de cualquier palabra una partícula transitoria, sobre todo si con ello se alcanza un efecto (de sonido selvático, de crecimiento subterráneo). Con el rizoma no solo se introduce una forma de argumento more botanico en contra del árbol ${ }^{15}$, de los binarismos y las relaciones biunívocas que operan en todos los niveles, sino que se da vida a una serie de imágenes del pensamiento ecológicas, de avispas y flores, de lobos, de huevos, del devenir-animal, incluso para caracterizar los estratos que imponen una organización: "Dios es un bogavante o una doble-pinza, un double-bind" (Deleuze \& Guattari, 2002, p. 48).

¿Qué tan sutil hay que ser para conducir microafectos? ¿Se trata, como sugiere Deleuze, de encontrar la potencia de un impersonal que no es una generalidad?

15 "El árbol y su trabajo de raíz todavía se parecen demasiado a lo Uno, lo Privilegiado, lo Monótono, atributos todos ellos que deben ser filosóficamente superados. Esta es la razón de que Deleuze y Guattari traten de sustituir el paradigma del árbol por una ramificación subterránea, una red en forma de hongo, una retícula micélica, una vida reticular de bulbos vegetales o excrecencias laterales. Ahora bien, en este desplazamiento de acentos, quizá se pasa por alto que el rizoma no constituye incondicionalmente una alternativa frente al árbol: también puede verse como la estructura más pobre y en todo caso más superficial, si tenemos en cuenta que todo lo que produce un micelio o un rizoma puede producirlo también un árbol a su manera, máxime cuando forma parte de un bosque, esto es, de un rizoma particular, y, además de hacer esto, origina una rica diferenciación vertical" (Sloterdijk, 2014, pp. 247-248). 
Es posible, pero tal vez no es deseable. Con frecuencia se ha calificado a Blanchot como escritor de lo impersonal; incluso Deleuze (1996) llegó a asociar lo neutro blanchotiano con la impersonalidad cuando puso como condición de la literatura el nacimiento de "una tercera persona que nos desposee del poder de decir Yo” (p. 8). Parece bastante obvio que, si la personología gramatical egocéntrica bloquea las intensidades lingüístico-literarias, basta con hablar desde las partículas impersonales - se, uno- para que las intensidades fluyan y sea posible producir multiplicidades en virtud de su diferencia. Quizás eso aclara la preferencia que tiene Deleuze por las novelas con "nombres propios que no son de personas" (Deleuze \& Parnet, 1980, p. 74), como la designación anónima del "joven soldado" de Stephen Crane (Deleuze, 2005, p. 134) y "el estudiante de idiomas demente", nombre con que Louis Wolfson se llama a sí mismo (Deleuze, 1996, p. 14). Con todo, nos preguntábamos hace un momento si solo un "yo" en retirada permite que las multiplicidades pasen por un texto. Puede que esto solo sea apropiado al nivel del punto de vista unívoco anclado en un individuo, pero la cuestión es más complicada al nivel del lenguaje. Lo es al menos en Blanchot (1994), que se pregunta por la posición de lo neutro -“¿personal? ¿Impersonal? Aún no y siempre más allá” (p. 35)-, y que comprende la lucha vana por el anonimato: "la impersonalidad no basta para garantizar el anonimato. La obra, aunque carezca de autor y esté siempre evolucionando con respecto a sí misma, delimita un espacio que atrae nombres" (p. 66).

No es necesario ir muy lejos en el examen de los discursos que pretenden abolir el "yo" (que usan fórmulas impersonales o figuras anónimas) para constatar que, lejos de liberar las intensidades, con ello solo se consigue satisfacer el imaginario del hablante, mientras que los estratos de personalización o subjetivación permanecen intactos $\mathrm{o}$, incluso, cobran más fuerza ${ }^{16}$. Semejantes recursos

16 Consideremos el discurso impersonal por antonomasia, la escritura académica. En ella se ha producido una "muerte del autor" (Barthes, 1994) que, lejos de socavar al buen Dios del significado y sus hipóstasis en virtud de una multiplicidad de voces y sentidos, ha hipostasiado al autor en una máquina burocrático-pedagógico-política titánica. Por lo impersonal no responde un anónimo ingenuo, sino la Academia y sus ramificaciones publicitarias. Lo mismo ocurre cuando escribe un nosotros que habla por la comunidad científica, el consenso general o cierta intelligentsia. Mi inconsistencia en el uso de personas, en la voz que recorre al texto, se explica en que no creo que los desplazamientos al nivel de la personología gramatical sean exclusivos de la gramática literaria, 
lingüísticos son equivalentes a lo que Barthes (2004) ha llamado las "precauciones oratorias" con que un hablante busca suavizar su soberbia, relativizando sus frases por medio de fórmulas de dubitación codificadas: "a mi humilde entender, por mi parte, creo que...” (p. 96). En varios momentos de su obra, Deleuze defiende lo impersonal en la gramática literaria, en una insistencia que remite a su confrontación con Husserl en Lógica del sentido: la batalla contra la "urdoxa" como facultad-matriz del sentido común en un sujeto trascendental que conserva la forma de la conciencia personal, de un "yo". En el trazo de un campo trascendental del empirismo superior, definido por una "conciencia pre-reflexiva, impersonal, duración cualitativa de la conciencia sin yo”, Deleuze (2008, p. 347) ha mostrado cómo la carga del "yo" inhibe la potencia de singularidades impersonales y preindividuales; pero aquí nos interesa mostrar que podría ser justamente el "yo" aquella partícula capaz de desplegar toda la fuerza de la diferencia allende la división entre lo personal y lo impersonal. En todo caso, Deleuze y Guattari (2002) se aproximan a esta cuestión en el programa del rizoma en Mil mesetas:

¿Por qué hemos conservado nuestros nombres? Por rutina, únicamente por rutina. Para hacernos nosotros también irreconocibles. Para hacer imperceptible, no a nosotros, sino todo lo que nos hace actuar, experimentar, pensar. Y además porque es agradable hablar como todo el mundo y decir el Sol sale, cuando todos sabemos que es una manera de hablar. No llegar al punto de ya no decir yo, sino a ese punto en el que ya no tiene ninguna importancia decirlo o no decirlo (p. 9; énfasis añadido).

Una breve consideración histórico-lingüística en torno a lo impersonal del lenguaje que socava al "yo" puede poner el problema en contexto: el lenguaje como el Otro del cual cada hablante es apenas un médium tiene familiaridad con el tropo de la abolición del ego que pasa por pensadores como Lacan -la "castración simbólica" por la que yo no hablo, sino que el lenguaje habla por mí (Žižek, 2012, p. 197) - o Barthes (1994):

es el lenguaje, y no el autor, el que habla; escribir consiste en alcanzar, a través de una previa impersonalidad -que no se debería confundir en ningún

mucho menos cuando intento mostrar que una máquina literaria puede abrir líneas de fuga en el lenguaje filosófico. 
momento con la objetividad castradora del novelista realista- ese punto en el cual solo el lenguaje actúa [...] y no “yo” (p. 67)

Lo impersonal tuvo una justificada época de gloria como antídoto contra el "yo pienso" cartesiano-kantiano y sus derivados en el marco del programa para terminar con el juicio del “yo”. No obstante, después de unas cuantas décadas de ensayos y repeticiones desnudas, el estilo impersonal ha perdido su filo. En la superficie se encuentra una razón psicopolítica o disciplinaria, la transmutación de un statement emancipatorio en una rutina o discurso fácilmente reproducible, calco sobre calco, cantinela. Una razón mucho menos obvia tiene que ver con la inclinación a hacer del lenguaje una nueva supraconsciencia o, más exactamente, una unidad trascendente que puede atravesar las multiplicidades en ciernes. A nivel lingüístico, quizás esto se debe a que las partículas impersonales -se, unorecorren una zona de variación que corresponde precisamente a la particularización. Por lo mismo, prescindir del “yo" - de la persona gramatical por excelencia (al menos desde la modernidad europea) - en un arranque de egofobia despoja al lenguaje de aquella partícula capaz de desplegar la serie de posiciones diferenciales que recorren el dinamismo de lo genuinamente impersonal.

Esto es algo que Deleuze (1996) comprendió cuando lo aplicó a un procedimiento que hace que la lengua "crezca por en medio, como si fuera hierba, lo que la convierte en rizoma en vez de árbol", entendiendo que se puede introducir un tartamudeo propio de un lenguaje afectivo sin la necesidad de partículas asignificantes (agregaríamos: impersonales), sino mediante términos altamente significativos (agregaríamos: personológicos), "sustantivos cada uno de los cuales definirá la zona de variación hasta la vecindad de otro sustantivo que determina otra zona” (pp. 176-177). Deleuze (1996) detecta ese modo de balbucear en la obra de Péguy y sus reinicios de lo irreiniciable: "Mater purissima, castissima, inviolata, Virgo potens, clemens, fidelis" (p. 156) que, incidentalmente, se aproximan por lo superlativo al umbral crítico donde no solo se desinfla la personología sino que se exceden los binarismos propios del lenguaje. Lo superlativo está siempre al borde del más allá. Si bien Deleuze (1996) reconoce que en este proceder las palabras quedan "intactas, completas y normales" (p. 177), no advierte que no son palabras cualesquiera, sino precisamente aquellas que, a fuerza de marcar la carga asertiva del lenguaje, casi lo hacen delirar. El delirio realmente ocurre cuando, como en el lenguaje de la teología negativa areopagita, el superlativo 
absoluto excede el binarismo, por lo que Barthes denomina "extra-vagancia" en los nombres de la deidad: "la más-que-buena, el más-que-dios, la más-que-viva, la más-que-sabia"; estas palabras forman las apófasis "que reúnen el superlativo (byper) y el privativo: el más allá y el más acá de la palabra” (Barthes, 2004, p. 263), con lo que se supera la negación lógica por una negación mística más allá del binarismo simple merced a la intensidad de lo privativo. La intensidad contra los binarismos no es siempre una mera pasividad correlativa a lo impersonal, sino que puede tomar una forma hiperbólica o extática.

\section{El deseo de lo neutro}

BARThEs (2004) -siguiendo a Blanchot, pero solo provisionalmente- ha llamado "lo Neutro" a todo aquello que desbarata el paradigma, es decir, que socava "la oposición de dos términos virtuales de los cuales actualizo uno al hablar" (p. 51). El programa de lo Neutro ${ }^{17}$ en Barthes es una reunión heteróclita de figuras capaces de desarmar las limitaciones de las bivalencias y, especialmente, las conminaciones a elegir entre los términos de una polaridad. Esto no solo incluye una deriva o deslizamiento frente a las oposiciones $(\mathrm{A} / \mathrm{B})$ sino también frente a las síntesis $(\mathrm{A}+\mathrm{B})$, las abstenciones (ni A ni B), y todo tipo de posiciones que puedan resultar dogmáticas, incluyendo aquellas que se suelen tomar por neutrales -lo Neutro no es neutral- como algunos tipos de silencio, de equilibrio o de anulación. En ese sentido, hay un "activo" de lo Neutro que lo aleja de la indiferencia, que remite a "estados intensos, inusitados" (Barthes, 2004, p. 52) y que busca "deshacerse de toda agresión y de toda destrucción, que despliega las diferencias sin jerarquía, que toca a fuerza de no tocar y mantiene a fuerza de retener" (Bident, 2012, p. 354). Es justo ese rasgo activo lo que abre un abismo de íntima cercanía entre lo Neutro barthesiano y lo neutro blanchotiano, porque, para Blanchot, lo neutro tiene la forma latina del ne uter -ni uno ni otro-, ni activo ni pasivo, pero, incluso, ni abstención ni síntesis reflexiva. Derrida ha comprendido bien el secreto de lo neutro en Blanchot como una pasión,

17 En realidad, no es un programa: en él se evitan los órdenes, las categorías, las directrices y, para esquivar cualquier dogmatismo que pudiera reintroducirlo en un paradigma, nada de eso se hace sistemáticamente. 
"la pasión de un pensamiento que no puede detenerse en cualquier opuesto sin superar también la oposición", y que, no obstante, está "más allá de toda dialéctica" (Derrida, 1998a, 121$).{ }^{18}$

Allende la diferencia entre la pasión de lo neutro en Blanchot y lo activo (pero sutil, afectuoso, quizás apasionado) de lo Neutro en Barthes, hay una denuncia común contra la lógica binaria que ha dominado en la historia del pensamiento europeo y que nos ha legado incontables restricciones que limitan las intensidades, que cortan todo devenir-múltiple. De todos los paradigmas o binarismos, quizás el más rotundo es el del bien y el mal, pues ha permitido cualificar los términos de todas las demás oposiciones, creando "jerarquías violentas" que nos conminan a estar en un punto que se supone óptimo, aquel que "gobierna al otro (axiológicamente, lógicamente, etc.) o lleva la delantera” (Derrida, 1972, p. 57 ${ }^{19}$. Las imágenes del pensamiento dominantes están atravesadas por esa "idiocia binaria", como la ha llamado Sloterdijk ${ }^{20}$ (2006, p. 30), y muchas empresas filosóficas no solo acogen esos binarismos sino que los exigen como fundamentos o centros de coherencia: verdadero/falso, bello/feo, sujeto/objeto, Dios/mundo, naturaleza/cultura, etc. De nada sirve introducir más términos en las oposiciones (por ejemplo, Dios/mundo/humano/historia) pues todas las

18 «la passion d'une pensée qui ne peut s'arrêter à aucun des opposés sans pour autant surmonter l'opposition»; « au-delà de la dialectique».

19 «commande l'autre (axiologiquement, logiquement, etc.), occupe la bauteur».

20 Sloterdijk (2011) acierta al mostrar el ámbito del problema, que en algunos sentidos es parafilosófico: "con ella [la lógica bivalente] no se pueden articular adecuadamente ni las concepciones fundamentales, hoy vigentes, sobre la constitución de los objetos naturales, ni las relativas a la manera de ser de los hechos culturales. Perseverar en las divisiones conceptuales tradicionales lleva a la incapacidad absoluta para describir de modo ontológicamente adecuado 'fenómenos culturales' como instrumentos, signos, obras de arte, leyes, costumbres, libros, máquinas y todos los demás artificios, pues en formaciones de este tipo, la división fundamental, propia de la cultura superior, de alma y cosa, espíritu y materia, sujeto y objeto, libertad y mecanismo, resulta inoperante: todos los objetos culturales sin duda son, por su constitución, híbridos con un 'componente' espiritual y otro material, y todo intento de decir lo que 'propiamente' son en el marco de la lógica bivalente y la ontología monovalente termina irremisiblemente en reducciones estériles y restricciones destructivas. Si se aceptan platónicamente las ideas como lo verdaderamente existente, la materia solo puede constituir una especie de no ser, y si se sustancializa la materia, las ideas quedan arrumbadas como no existentes y epifenomenales. Estos errores y restricciones no son, naturalmente, equivocaciones de personas: ellos muestran los límites de una gramática" (p. 141). 
oposiciones pueden remitir, en última instancia, a una relación biunívoca; con ellas se ha excluido la posibilidad del "tertium datur" (Sloterdijk, 2011, p. 142), que, según la filosofía en cuestión -sin pretender con esto una convergencia- ha tomado el alias de neutro, différance, espuma, etc. Por eso dice Blanchot (2008): "se podría reconocer, en toda la historia de la filosofía, un esfuerzo ya sea por aclimatar y domesticar [lo] 'neutro', sustituyéndolo por la ley de lo impersonal y el reino de lo universal" (p. 380). Frente a ese panorama, lo neutro sería la ciencia de todo (no) más allá del bien y del mal, aunque la forma en que se da le pas audelà es lo problemático mismo de toda filosofía por venir.

Una salida interesante al binarismo, pero insuficiente pues reduce la diferencia a la oposición, es la coincidencia de los opuestos, presente desde hace mucho tiempo en la coniunctio de los alquimistas medievales que serían -en ese sentido- hegelianos prematuros. Es sabido que debemos a Hegel la polivalencia del pensamiento con su nueva lógica (Sloterdijk, 2006), pero el tercero que emerge con la Aufbebung determina la diferencia solo para resolverla, "para interiorizarla, para relevarla (de acuerdo con el proceso silogístico de la dialéctica especulativa) en la presencia ante sí de una síntesis onto-teológica u onto-teleológica" (Derrida, 1972, p. 60) ${ }^{21}$. Y, sin embargo, por mucho que nos esmeremos en cuidar la diferencia, nunca es fácil dejar atrás a Hegel. El propio Derrida (1972) admite que la différance señala el punto en que se rompe con la Aufhebung justo en una "proximidad casi absoluta a Hegel" (p. 44) ${ }^{22}$. Algo así ocurre con lo neutro en Blanchot (1994):

Lo neutro, nombre paradójico: no habla casi, palabra muda, simple que, sin embargo, se vela siempre se desplaza siempre fuera de su sentido, operando sobre sí mismo de forma invisible sin cesar de desenrollarse, en la inmovilidad de su posición que repudia toda profundidad. (El)lo neutraliza, (se) neutraliza, evocando de ese modo (no haciendo más que evocar) el movimiento de la Aufhebung, pero si (el)lo se suspende y retiene, solo retiene el movimiento de suspender, es decir, la distancia que suscita por el hecho de que, al ocupar

21 «pour [...] lintérioriser, la relever, selon le processus syllogistique de la dialectique spéculative, dans la présence à soi d'une synthese onto-théologique ou onto-téléologique ».

22 «roximité presque absolue avec Hegel 》. 
el terreno, la hace desaparecer. Lo neutro designa, entonces, la diferencia en la indiferencia, la opacidad en la transparencia [...] (p. 106).

Aquí conviene resistir toda inclinación (¿hábito?, ¿costumbre?, ¿domesticación?) interpretativa, porque lo neutro ha creado una distancia tan sutil que el lenguaje de la razón amenaza con dominarla. Quizás el lenguaje de la locura podría intervenir -irrumpir, interrumpir- ahora, aun si por eso nos exponemos "a la burla de la buena conciencia filosófica, aquella que cree poder mantenerse a la sombra de las Luces” (Derrida, 1998b, p. 62). Quizás. Parafraseando a Deleuze, corresponde hacer delirar el lenguaje filosófico. Una vez más, con Blanchot (1994): "la locura significa entonces: nadie traspasa el umbral, salvo por locura, y la locura es el afuera que no es más que el umbral” (p. 152). Y quizá necesitamos una ruptura que nos absuelva "no solo de toda la razón (esto sería poco), sino de toda 'sinrazón', es decir, de esta razón que es todavía la locura” (Blanchot, 2008, p. 98). Quizás esto es lo neutro: no solo el más allá del pensamiento bivalente, como ha mostrado Barthes, sino el umbral que lo circunda sin definirlo, la locura que se inocula en él y lo desorganiza, ensombreciendo sus tendencias de ramificación biunívoca. De allí se desprende una tentativa: toda máquina literaria, incluso cualquier máquina, funciona por operaciones de lo neutro que desarman los binarismos y problematizan todo límite; de lo contrario, las cosas seguirían el curso predefinido de las bifurcaciones, de las articulaciones en los estratos que aprisionan intensidades. Con lo neutro se abren líneas de fuga para lo fragmentario, para que bloques incongruentes se conecten por su propia diferencia, para que flujos delirantes circulen en todas las direcciones. Un mapa afectivo, eso es lo que traza lo neutro; ya Barthes (2004) lo había insinuado: "el discurso llega a lo Neutro por el afecto” (p. 254).

Repitamos la cuestión de si solo en virtud de una impersonalidad lingüística o del recurso de los nombres anónimos se alcanza un flujo libre de intensidades. Puede ser que el "yo" abra la huella de lo neutro. Pues lo neutro no se inscribe en la gramática de una negación: no es una distancia sin más, lo impersonal de un ne uter, sino una distancia sin distancia, y aquello que Deleuze y Guattari han considerado un enorme punto de bloqueo es, tal vez, la singularidad más potente. No da lo mismo si se mienta o no aquel "yo", como imaginaron en el programa del rizoma; es necesario decirlo, hacerlo delirar, diseminarlo, hacerlo estallar en una gran multiplicidad (Nietzsche [2016b]: "yo no soy un hombre, 
soy dinamita" [p. 853]). Cuando Artaud (1975) dijo “yo, Antonin Artaud, soy mi hijo, mi padre, mi madre y yo" (p.67), estaba jugando con la potencia infinita del devenir múltiple del "yo", pero Deleuze y Guattari no lo vieron así porque su programa iba contra los fantasmas del triángulo edípico en el juego del esquizo ante el sobrecodificador analista. Artaud muestra a viva voz, subvirtiendo lo que propone Deleuze (1996), que no es preciso "destruir el yo" (p. 180) para ser un gran escritor; a eso añadiremos que no hay que entrar en la monotonía de un "ello" antiedípico para producir multiplicidades, olvidando la invitación de Nietzsche (2016b) a que aprendamos a arreglárnoslas "sin aquel 'ello' al que ha quedado reducido el viejo y honesto yo" (p. 308).

Nietzsche se cuenta entre los pocos filósofos que han sabido hacer de su nombre toda una intensidad de lo neutro, desatando con esto la locura de la transvaloración que invierte todos los sentidos, que, lejos de hablar en impersonalidades, dice lo múltiple con un "yo" hipermóvil, alegre, "en el riesgo extraviado del nombre propio [...] en los límites del histrionismo" (Barthes, 2004, p. 174). El "yo" que parece afirmarse con una violencia inédita se invierte, o, mejor, se disemina en el momento mismo en que se proclama, e incluso puede que lo haga en la inminencia de su proclamación. A eso se refiere Blanchot (2008) cuando observa que

contradecirse es el movimiento esencial [del pensamiento de Nietzsche]; cada vez que afirma, la afirmación tiene que ponerse en relación con la afirmación opuesta; el punto decisivo de todas sus certidumbres pasa por la impugnación, la supera y vuelve a ella (p. 183).

A propósito de lo egoico en su escritura, Sloterdijk comprende que lo que apresuradamente se ha despachado como megalomanía o narcisismo en Nietzsche no es sino la efectuación pura de una transvaloración que explosiona la bivalencia del discurso humilde. Sloterdijk (2013) opera una despsicologización del "acontecimiento discursivo que lleva por nombre Nietzsche" (p. 51) para explicar que su estilo autolaudatorio -su composición de un quinto evangelio- es menos un fenómeno atinente a la psique de un individuo y más un quiebre en la historia lingüística de la vieja Europa. No hay otro camino auténtico para la comunicación de la buena nueva más que la autoafirmación, en todo caso aporética, de una vida que se realiza como composición artística: 
Podríamos llamar spinozistas a las huellas lingüísticas de una vida semejante en el sentido de que sirven para anunciar una fuerza del ser. Dichas huellas rompen los límites de la lógica bivalente tradicional, que siempre han exigido que el hablante escoja una entre dos cosas: o bien responder por dios, lo cual se hallaba inevitablemente conectado con el rechazo del ego odioso, o bien responder por el Ego, lo cual solo podía entenderse tradicionalmente como la renuncia satánica a dios (Sloterdijk, 2013, pp. 56-57).

Solo podemos decir, de paso, apenas indicando, que en Nietzsche lo neutro es la potencia de un fatum donde la lógica bivalente se disloca para co-implicar los opuestos en un pliegue. En el Ecce homo esto se reconoce como el acertijo de una fatalidad. Dice Nietzsche (2016b): "como mi padre, ya estoy muerto; como mi madre, sigo vivo y voy envejeciendo” (p. 785). Ser al mismo tiempo "décadent y comienzo" es lo que explica "esa neutralidad, ese estar libre de partidismo [...] que quizá sea lo que me distingue” (p. 785). Pero lo que mueve su filosofía no es una síntesis sin más que cancela las tensiones, sino, como dice Blanchot (2008), una pasión, un "Dasein sin Sein" en que los términos se dan en una yuxtaposición "que no los confunde, no los distingue, no los pone en relación y, así, responde a la exigencia de la escritura fragmentaria” (p. 213). Entre los fragmentos yuxtapuestos, no negados ni afirmados, aparece "lo ilimitado de la diferencia" (p. 201). Desgraciadamente, no podemos demorarnos en un examen de lo neutro como potencia en las huellas yoicas de Nietzsche. Esto es nada más que un comentario al margen, liminal y limitado, sobre una manera de deshacer las bivalencias del discurso por la vía de un "yo" que ha sido visto como demasiado asertivo, cuando no ha sido más que una fuerza contra la asertividad. Y, con todo, indiquemos algo más: en El nacimiento de la tragedia hay una semilla sobre el genio creador que yuxtapone, cual si abriera un plano de inmanencia, las instancias de la escritura como pasión en que se deviene "a la vez sujeto y objeto, a la vez poeta, actor y espectador" (Nietzsche, 2016a, p. 355) y que, de paso, anuncian un procedimiento que ya observamos en Musil y que Derrida encuentra en Blanchot cuando lee la obra autobiotanatográfica El instante de mi muerte. A esa potencia metonímica que complica la personología de la gramática literaria, que mueve la repetición de los pronombres y personajes en su afuera, dedicaremos la sección final. El cierre del artículo será la apertura de la máquina literaria de Maurice Blanchot. 
4. El paso/no más allá

LA ESCRITURA DE BLANCHOT es fragmentaria, en primera instancia, por el juego de diferentes fuentes tipográficas, entrecomillados, rayas, cursivas, diálogos, aforismos, sentencias y marcas (como la inscripción de comentarios precedidos por “ \pm \pm ” en L'entretien infini o " aclara el propio Blanchot (1994), la escritura fragmentaria no está dada ni por "el fragmento, parte de un todo, ni [por] lo fragmentario en sí mismo" (p. 74). El trabajo de lo fragmentario es subterráneo en relación con los fragmentos que se inscriben en la escritura. Lo que se desplaza en ella no es (solamente) cierta estructura sintáctica, sino el sujeto como el "locus de la presencia ante $\sin ^{\prime \prime 23} \mathrm{y}$, con él, "la identidad en general, y finalmente el presente mismo" (Nelson, 1992, p. $\mathrm{x})^{24}$. Ese desplazamiento se repite en la serie de sus escritos y en la diferencia que hace la escritura. Incluso se repite en el título de Le pas au-delà, en que el pas es la huella de lo negativo (ne-pas), de la prohibición, $y$ del paso (pas) o transgresión. El juego de palabras anuncia la pasión de lo neutro que abre el límite como un indecidible: ni posible ni imposible, sino (aún no, siempre ya) el paso no/más allá, transgresión nunca victoriosa, siempre en peligro de atraer el nombre de lo trascendente, de lo sagrado que limita la prohibición estéril. Por eso, la escritura fragmentaria no toma su potencia de los fragmentos que invitan a un cruce sino de la distancia que crece íntima, infinitamente en el entre:

Escribir arrastra, arranca, por la plural dispersión de su práctica, todo horizonte y todo cimiento, arrastrando con un arrebato que no tiene tiempo de desplegarse, que puede, por lo tanto, ser calificado de súbito, lo mismo que una marca que no tendría tiempo (disponiendo de todo el tiempo) de dejar huellas, arrastrando el límite que no es tal más que por la exigencia de un ['siempre ya'], prohibido a causa de la transgresión o infranqueable si, o desde que, ya es franqueado e inmediatamente, y al mismo tiempo, apartado de todo franqueamiento (de toda franqueza). El ['aún no'] del pensamiento, el ['siempre ya'] de la escritura, se inscriben de acuerdo con los intervalos

23 "The locus of self-presence."

24 "Identity in general, and finally the present itself." 
que ambos mantienen o ponen al descubierto, pero que no se superponen (Blanchot, 1994, p. 87).

La atracción de una transgresión que se cumple "no cumpliéndose" (Blanchot, 1994, p. 107) lleva la huella de lo neutro, pues lo neutro es aquello que debe transgredirse. Con Blanchot, ningún cruce, ninguna travesía es reconfortante, aun cuando la aproximación al límite permita problematizar las pretensiones del pensamiento que intentan subsistir en la escritura: la acogida de una interioridad en orden, la tranquilidad de un sistema o totalidad, la guía decisoria de una lógica binaria. Todo cruce es, en su inminencia, un desvío asintótico que esquiva el límite y que repite, que hace retornar la transgresión como prohibición. No es así en Barthes (2004), pues, para él, lo Neutro "no es un objetivo o un blanco: es una travesía" (p. 118): el activo de lo Neutro permite hablar de haber atravesado un sistema, incluso por derivas que dejan atrás la cuestión del fundamento. Por eso Barthes relaciona lo activo de lo Neutro con la huida de Euríloco (discípulo de Pirrón) como reacción al paradigma del debate, a las obligaciones de toma de posición: "otra vez, en Élida, cansado de las preguntas que le hacían sus discípulos, se desvistió y, para huir de ellos, atravesó el Alfeo a nado" (p. 166) ${ }^{25}$. Pero uno puede imaginar a Euríloco arrastrado por la corriente del Alfeo a otro lugar donde los discípulos han estado siempre ya esperando, prohibiendo su travesía; así, quizá, lo habría visto Blanchot, y aun cabe imaginar que ni siquiera el cruce del Leteo traerá consigo la serenidad del olvido.

Convencionalmente, la muerte se toma como modelo de límite en el sentido de la vida en que la materia retorna, entrópicamente, a lo inanimado (tal es el sentido freudiano en la formulación de la pulsión de muerte). Sin embargo, como observa Deleuze (2002) en sus comentarios sobre Blanchot en Diferencia y repetición, hay una muerte "presente en lo viviente como experiencia subjetiva y diferenciada [...], forma vacía del tiempo [...], forma última de lo problemático, la fuente de los problemas y de las preguntas" (pp. 176-177). Es esa muerte indefinida, esa experiencia inexperienciable, la que nos arrastra a cada instante fuera del instante mismo. Muertos en la inminencia de aquello que, al no ocurrir, acontece, estamos en adelante siempre muriendo y, sin embargo, desposeídos del

25 Barthes recoge la historia de Diógenes Laercio. 
poder de morir, vedados por el llamado de una transgresión que se corta en su paso/no más allá. Por eso, cuando en Le dernier homme alguien dice: "me convencí de que lo conocí primero cuando estaba muerto, luego cuando estaba muriendo" (Blanchot, 1957, p. 11), no se trata apenas de una praposteratio que invierte el orden temporal acostumbrado: la inminencia de la muerte se consuma en una virtualidad que deja la muerte por venir como una experiencia indefinida, inexperienciada, incruzable.

Lo neutro es esa muerte ${ }^{26}$, esa "dulce interdicción del morir [...] habla todavía por decir más allá de los vivos y de los muertos, que testifica por la ausencia de atestación" (Blanchot, 1994, p. 107). Ser testigo de aquello de lo que nadie puede dar testimonio, de la propia muerte, es la exigencia misma de la escritura fragmentaria que marca la pasión del afuera en Blanchot. Es cierto que hay una instancia ejemplar de esa exigencia en L'instant de ma mort (Blanchot, 2000), el relato autobiotanatográfico de su muerte, en 1944, frente a un pelotón de fusilamiento durante la ocupación alemana. Pero, como apunta Derrida, esa instancia marca "la repetición de lo que siempre ya se habrá dicho en los textos anteriores de Blanchot" (Derrida, 1998a, p. 61) 27. La repetición de lo que Blanchot (2000) ha llamado "el encuentro de la muerte y de la muerte" (p. 4$)^{28}$ invoca a lo neutro como fuerza de lo fragmentario allí donde, en la inmediatez que aproxima lo por venir y lo ya pasado, abre un espacio que hace posible toda escritura. Toda escritura está atravesada por esa interrupción que pliega lo virtual y lo real. Blanchot (2008) entiende que las interrupciones más prosaicas -espacios entre palabras, pausas entre interlocutores, suspensos de atención- constituyen la condición de toda sucesión de palabras, la "intermitencia [que] hace posible el devenir, la discontinuidad [que] asegura la continuidad de la escucha” (p. 94). Pero hay otro tipo de interrupción que anuncia "la extrañeza, la infinidad entre nosotros", no dada por las pausas o silencios sino por "un cambio en la forma o la estructura

26 "Admitamos que lo neutro no pertenece al lenguaje de los vivos [...] y quizás habría que decir que el pueblo de los muertos es el que lo repetiría con mayor reticencia, ciertamente no porque sería un eco nostálgico del mundo de los vivos (nada vivo hay en él) sino porque, al escucharlo, correrían el riesgo de enterarse de que aún hay algo más muerto que la muerte" (Blanchot, 1994, p. 116).

27 « la répétition de ce qui aura toujours été dit dans les textes antérieurs de Blanchot».

28 «la rencontre de la mort et la mort». 
del lenguaje $[. .$.$] comparable metafóricamente al que hizo con la geometría de$ Euclides la de Riemann" (p. 96). En ese campo disimétrico, en esa superficie de Riemann, la escritura fragmentaria abre una grieta que no reúne los fragmentos, sino que se vacía, desafiando cualquier pretensión de unidad.

Lo fragmentario que abre una distancia infinita (la intimidad del afuera) entre las instancias de la escritura se nutre de una repetición sin origen que hace de todo escribir un reescribir, no en referencia a "ninguna escritura previa [ni] a una anterioridad de habla o de presencia o de significación", sino como repetición de "lo que no tiene lugar, no tendrá lugar, no ha tenido lugar" (Blanchot, 1994, pp. 62-63). Leyendo a Blanchot, Derrida observa que cada instante es indefinidamente repetible y está "siempre dividido en este preciso punto, en el punto de su escritura” (Derrida, 1998a, p. 48)29. En L'instant de ma mort, el encuentro con la muerte frente al pelotón nazi (más tarde, soviético) hace proliferar las instancias de la escritura en una repetición metonímica que complica la estructura de la personología gramatical. El "instante de mi muerte", al ser repetido en la escritura, fragmenta al "yo" del autor que se disemina en el "yo" del narrador, el cual, a su vez, habla de un "yo" joven que fue vedado de morir por la muerte misma cincuenta años antes ${ }^{30}$. El pronombre se repite en su afuera, que no es la marca de otra persona gramatical y, por eso mismo, hace de la cercanía una distancia todavía más inquietante. Las instancias del autor, el narrador y el personaje no son de ningún modo el mismo "yo", aun si los acerca -como muestra Derrida- la (com)pasión de la literatura y la muerte: "nadie se atreverá a asumir el derecho, porque nadie lo tendrá nunca, de decir que estos tres yoes son el mismo; nadie responderá nunca por esta identidad de la compasión" (Derrida, 1998a, p. 93) ${ }^{31}$.

Casi al final de L'instant de ma mort hay otra repetición de la instancia pronominal del "yo" (nombrado como un "él") en su afuera, en un cruce que abre una distancia del todo diferente: "yo sé, imagino que este sentimiento inanalizable

29 « t'instant dès lors se divise toujours à sa pointe même, à la pointe de son écriture ».

30 Todavía hay otro "yo" diseminado en la máquina epistolar (de la amistad) que firma una carta dirigida a Derrida: "Julio 20. Hace cincuenta años, conocí la felicidad de casi ser fusilado" [ « Juillet 20. Il y a cinquant ans, je connus le bonheur d'être presque fusillé » (Derrida, 1998a, p. 64).

31 «Personne ne osera prendre le droit, parce que personne ne l'aura jamais, de dire que ces trois je sont le même, personne ne répondra jamais de cette identité de compassion ». 
cambió lo que le quedaba de existencia. Como si la muerte afuera de él solo pudiera en adelante chocar con la muerte en él. "Estoy vivo. No, estás muerto" (Blanchot, 2000, p. 8) 32 . La transgresión (más clara aquí) de la gramática literaria habitual hace patente, marcándola, la prohibición. En la obra de Blanchot hay varios ejemplos (varias instancias) en que se acomete ese paso/no más allá de una instancia a otra - por la fuerza de lo neutro que abre lo indecidible sin poder permanecer en él-, y no solo en el orden de lo personológico, sino también de lo semántico, de lo ortográfico, y, en fin, virtualmente de cada sistema que organiza la escritura. Si nos hemos decidido por la estructura de la personología gramatical, esto ha sido por su fuerza jerarquizadora, que remite tan fácilmente a la noción de límite bien definido como garantía de una interioridad apaciguada. Las series de pasos/no más allá que repiten las instancias de la literatura pueden verse como simples transposiciones aleotéticas -retóricamente defendidas-, pero, de nuevo, lo enigmático no es en cada caso la singularidad que aparece en la repetición, sino la distancia que se abre con la transgresión-prohibición. Hay un espacio de extrañeza poética presente en algunos de estos pasos, como se ve en Le dernier homme:

¿Qué hay ahora aparte de nosotros? Nadie. ¿Quiénes son los distantes y quiénes los cercanos? Nosotros aquí y nosotros allá. ¿Y quiénes son los más viejos, y quiénes los más jóvenes? Nosotros. ¿Y quién debe ser glorificado, quién viene hacia nosotros, quién espera por nosotros? Nosotros. Y el Sol, ¿de dónde obtiene su luz? De nosotros y solo de nosotros. Y el cielo, ¿qué es exactamente? La soledad que hay en nosotros. ¿Entonces quién debe ser amado? Yo (Blanchot, 1957, pp. 112-113).

Es entre esos fragmentos - marcados por lo neutro, por la muerte- donde se expresa la máquina literaria de Blanchot: hiatos entre personas, palabras, autores, obras, instantes, lectores... donde proliferan multiplicidades: espacios que se abren infinitamente, indecidibles e inhabitables, que no pertenecen por derecho propio a la escritura fragmentaria (pues su pasión consiste en borrarse) pero que en ella brillan como indicios de un afuera, de lo otro en cuanto otro. La máquina literaria opera por lo neutro con una indecidibilidad que ni siquiera se aventura a pensar en una travesía, pues todo paso que cruza un límite, al

32 «e suis vivant. Non, tu es mort ». 
declararse victorioso, amenaza con reintroducir el afuera en la seguridad de lo pensable, de lo apresable por la escritura. De ahí la pasión de lo neutro que problematiza el límite para no aprisionar la diferencia.

La máquina literaria de Blanchot no se contiene en su escritura, ni siquiera en la multiplicidad de lectores que forman a su lado una comunidad sin comunidad. Es tentador concluir que solo la escritura fragmentaria marca los hiatos que muestran cómo la diferencia escribe por repeticiones. Pero lo fragmentario está siempre ya en todo lenguaje y todo pensamiento, es la imposibilidad misma de su posibilidad que, diciendo al ser, intentando capturarlo en su presencia, no lo dice: lo pierde. Lo fragmentario está incluso en los pensamientos más seguros de sí, en los sistemas protegidos por un fundamento legitimador. Por eso, la máquina literaria de Blanchot deviene una forma de lectura atenta a los espacios justo allí donde parece que han sido llenados, en la violencia monológica, en el habla que pontifica -que erige puentes para anular cualquier distancia- y que pretende imponerse por la gravedad de su expresión. En consecuencia, la máquina se sustrae a cualquier sistematización, ya en una teoría literaria, ya en una filosofía centrada en lo neutro como concepto (lo neutro está más acá, más allá del concepto, y por eso se neutraliza, se borra cuando se dice, se disemina en la muerte).

Una lectura maquínica que repita las pasiones literario-filosóficas de Blanchot no podrá forzar la interiorización del afuera por la vía de lo neutro, sino que deberá buscar lo neutro como huella en el vacío de las palabras, en el silencio de su extinción. Así parece imaginarlo Blanchot (1973) en un ruego místico, un murmullo: " injertado en cada palabra: lo neutro" (p. 117)

\section{Referencias}

Aristóteles. (1996). Acerca del cielo. Meteorológicos. (Trad. M. Candel). Madrid: Gredos.

Artaud, A. (1975). Para terminar con el juicio de Dios y otros poemas. Buenos Aires: Ediciones Caldén.

$33 \ll$ Greffé sur toute parole : le neutre ». Uso aquí mi traducción de la versión original en francés, pues en la traducción disponible en español el sentido queda trastocado. 
Barthes, R. (1994). El susurro del lenguaje. Más allá de la palabra y de la escritura. Barcelona: Paidós.

Barthes, R. (2004). Lo neutro. Notas de cursos y seminarios en el College de France, 1977-1978. Ciudad de México: Siglo XXI Editores.

Bident, C. (2012). R/M, 1953. Instantes y Azares. Escrituras nietzscheanas, 343-360.

Blanchot, M. (1950). Thomas l'obscure. París: Gallimard.

Blanchot, M. (1957). Le dernier homme. París: Gallimard.

Blanchot, M. (1973). Le pas au-delà. París: Gallimard.

Blanchot, M. (1994). El paso (no) más allá. Barcelona: Paidós.

Blanchot, M. (2000). L'instant de ma mort / The Instant of My Death. En: M. Blanchot, \& J. Derrida, The Instant of My Death / Demeure (pp. 1-12). Stanford: Stanford University Press.

Blanchot, M. (2005). El libro por venir. Madrid: Trotta.

Blanchot, M. (2008). La conversación infinita. Madrid: Arena Libros.

Deleuze, G. (1972). Proust y los signos. Barcelona: Anagrama.

Deleuze, G. (1996). Critica y clinica. Barcelona: Anagrama.

Deleuze, G. (2002). Diferencia y repetición. Buenos Aires: Amorrortu.

Deleuze, G. (2005). Lógica del sentido. Barcelona: Paidós.

Deleuze, G. (2008). Dos regimenes de locos. Textos y entrevistas (1975-1995). Valencia: Pre-Textos.

Deleuze, G., \& Guattari, F. (1990). Kafka. Por una literatura menor. México D. F.: Ediciones Era.

Deleuze, G., \& Guattari, F. (2002). Mil mesetas. Capitalismo y esquizofrenia. Valencia: Pre-Textos.

Deleuze, G., \& Guattari, F. (2016). El Antiedipo. Capitalismo y esquizofrenia. Barcelona: Paidós.

Deleuze, G., \& Parnet, C. (1980). Diálogos. Valencia: Pre-Textos.

Derrida, J. (1972). Positions. París: Les Éditions de Minuit.

Derrida, J. (1998a). Demeure. Maurice Blanchot. París: Galilée.

Derrida, J. (1998b). Politicas de la amistad seguido de El oído de Heidegger. Madrid: Trotta.

Derrida, J. (2006). Márgenes de la filosofía. Madrid: Cátedra. 
Heidegger, M. (2015). Reflexiones II-VI. Cuadernos negros (1931-1938). Madrid: Trotta.

Kafka, F. (2012a). Ante la ley. Bogotá: Random House Mondadori.

Kafka, F. (2012b). El silencio de las sirenas. Bogotá: Random House Mondadori.

Mathews, J. (1948). A Note on Valéry. En: P. Valéry, Monsieur Teste (pp. v-xiv). Nueva York: Alfred A. Knopf.

Musil, R. (2012). El hombre sin atributos (Vol. I). Barcelona: Seix Barral.

Nelson, L. (1992). Introduction. En: M. Blanchot, The Step Not Beyond (pp. v-xxi). Nueva York: State University of New York Press.

Nietzsche, F. (2016a). Obras completas (Vol. I). Escritos de juventud. Madrid: Tecnos.

Nietzsche, F. (2016b). Obras completas (Vol. IV). Escritos de madurez II y Complementos a la edición. Madrid: Tecnos.

Proust, M. (2015). A la busca del tiempo perdido. (M. Armiño, Trad.) Madrid: Valdemar.

Rumi. (2005). The Book of Love. Poems of Ecstasy and Longing. (Trad. C. Barks). California: HarperCollins.

Sloterdijk, P. (2006). Esferas III: Espumas. Madrid: Siruela.

Sloterdijk, P. (2011). Sin salvación. Tras las huellas de Heidegger. Madrid: Akal. Sloterdijk, P. (2013). Nietzsche Apostle. Los Ángeles: Semiotext(e).

Sloterdijk, P. (2014). El Sol y la muerte. Madrid: Siruela.

Valéry, P. (1960). Monsieur Teste. En: CEuvres II. La Pléiade (pp. 14-157). París: Gallimard.

Žižek, S. (2012). Less Than Nothing. Hegel and the Shadow of Dialectical Materialism. Nueva York: Verso. 